Otterbein University

Digital Commons @ Otterbein

\title{
Not So Revolutionary After All: The Role of Reinforcing Frames in US Magazine Discourse about Microcomputers
}

Jean P. Kelly

Otterbein University, jkelly@otterbein.edu

Follow this and additional works at: https://digitalcommons.otterbein.edu/comm_fac

Part of the Communication Commons

\section{Repository Citation}

Kelly, Jean P., "Not So Revolutionary After All: The Role of Reinforcing Frames in US Magazine Discourse about Microcomputers" (2009). Communications Faculty Scholarship. 4.

https://digitalcommons.otterbein.edu/comm_fac/4

This Article is brought to you for free and open access by the Communication at Digital Commons @ Otterbein. It has been accepted for inclusion in Communications Faculty Scholarship by an authorized administrator of Digital Commons @ Otterbein. For more information, please contact digitalcommons07@otterbein.edu. 


\title{
Not So Revolutionary After All: The Role of Reinforcing Frames in US Magazine Discourse about Microcomputers
}

\author{
Submitted to New Media \& Society
}

\section{Abstract}

This study investigates the role of media discourse in the hegemonic process by which the microcomputer became a common and trusted appliance in the US during the early years of the technology's adoption: the 1980s-90s. Using critical discourse analysis along with framing theory, analysis of four cases from consumer magazines- two advertisements and two editorial feature stories - revealed that a device heralded as 'revolutionary' was in fact presented using rhetoric that incorporated and legitimized traditional values, roles, and practices, such as capitalism. Any frames that potentially challenged existing social structures and power relationships were secondary and 'superframed' by the reinforcing frames.

KEYWORDS: computers, ICTs, framing, critical discourse analysis, US magazines, media discourse, marketing 


\section{Not So Revolutionary After All: \\ The Role of \\ Reinforcing Frames in US Magazine Discourse about Microcomputers}

When the microcomputer was first introduced 1974 in the US as a do-it-yourself project for electronics tinkerer, the devices had little to no practical domestic application (Winston, 1998). By 1995, 35 million US households contained at least one personal computer compared to just a few hundred homes twenty years earlier. More than half of those households, 20 million, included children, and no less than 96.5 percent of those families had bought educational software (p. 237). In 199842 percent of households owned a PC and one-quarter had access to the Internet (Papdakis and Collins, 2001). This study investigates some of the institutional, social, and political processes by which the once-threatening wartime devices became common and trusted home appliances, one that middle- and upper middle class families at the turn of the new millennium considered essential for daily life and invested with their hopes for success and happiness. More specifically it seeks to explore the role of media discourse, both editorial and advertising texts in magazines, in defining the uses and values of computers.

This diffusion of microcomputing into almost all aspects of social life in the late $20^{\text {th }}$ century was called 'revolutionary' by many and merely 'evolutionary' by others ('Revolutionary’ by Robertson 1998, Gilster 1997; 'evolutionary’ by Fidler, 1997, Winston 1998). But despite the pervasiveness of the technology, the impact of computers, 
particularly in the home, is not yet well-understood (Papadakis and Collins, 2001). Advocates of media literacy and citizen involvement in media policy have called for a better understanding of the influence of information technology, noting that the increasing naturalization and transparency (the tendency for origins of content and functionality to be hidden behind simulated interfaces) of computers requires use of a more sophisticated form of media and social criticism (Turkle 1995; Warnick 2002).

The significant influence of the news media on the dissemination of new technologies across the years has been acknowledged and studied by many scholars, especially those who espouse diffusion theory (Rogers 1983). Both Gitlin (1980) and Cogan (2005) recognized that examining early media coverage of an event helped 'discover the original frames and see them harden into the taken-for-granted conventional wisdom, the hegemonic definition of how things are' (Cogan 2005: 254). Only a few researchers, however, have systematically analyzed media texts in depth in order to understand not only the role of these texts in constructing a culture that accepted computers, but also to understand the political, social and cultural influences acting on the text producers and how these forces influenced the texts (Thurlow 2006).

This study attempts to apply that 'sophisticated form of media and social criticism' by combining several theoretical perspectives and discourse methodologies. At its core it is informed by social construction of technology theory (SCOT), which assumes that society is as much an influence on the development of a new technology as the other way around (Marx and Smith, 1994). That is, the nature and meaning of technology is determined by interested sponsors. In this view, it is a network of institutions and individuals that collectively determine what is important about a device; therefore evaluations of a technology, such as those in the media, are not objective, but 
derived from the values, needs, and interests of particular groups (Westrum 1991). Therefore, the current study endeavors to investigate how media texts about computer adoption were influenced by macrosocial factors, particularly the agendas of computer manufacturers, government and media decision makers, and how power relationships are evident in specific, tangible textual characteristics, specifically 'frames.'

Much of the public discourse about microcomputers first took place in US magazines. Microcomputers were first introduced as make-at-home kits in hobby magazines; Radio-Electronics and Popular Electronics introduced the first true 'home computers,' which could be constructed from kits available from the publishers (Titus, 1974). Several authors have asserted that magazines then continued to play a unique and significant role in both identifying and creating a consumer market for microcomputers by defining the characteristics of the innovation that aided its diffusion (Frieberger and Swaine, 1984; Rogers 1983; Rogers et. al., 1982; Winston, 1998). It is possible that the negotiations involved between sponsors of the new technology, text producers, and their audiences, remain observable in magazine stories and advertisements, preserved as frozen moments in a continuous stream of social interactions. Spigel, for example, found that when she compared audience research studies about television's impact on daily life to media discourse about television in magazines, the similarities were 'remarkable.' 'This correspondence between social scientific studies and popular texts suggests that the discursive rules for speaking about the new medium were highly conventionalized' (Spigel, 1992: 6) That is, popular media, including magazine texts and advertisements, can be explored as 'a ground for cultural debate' (p. 8).

The time period represented in this study, the mid-1980s-90s, was chosen because it brackets several events that potentially influenced discourse surrounding use of 
computers in the US. By 1981, the microcomputer industry had reached the billion dollar mark and IBM introduced its 'PC.' Big Blue's entry into the market meant the diffusion entered a new phase, one influenced by realignment in the industry, bankruptcies by some of the pioneering companies, and eventually the growth of a mass consumer market (Carlton, 1997). In 1984 computers with the graphical user interface (GUI) of icons, menus and the desktop metaphor were introduced by Apple Computer; for the first time computers were mass-marketed as 'friendly' 'information appliances' Campbell-Kelly and Aspray 1996: 271). But after a steady climb over seven years, the adoption rates for home computers leveled off in 1985 (Rogers et al., 1982) This prompted a broad-based marketing effort by manufacturers and retailers that targeted women and families in particular as computer buyers (Cassidy, 2001; Johnson, 1990; Petre, 1983) By 1990 adoption rates began to rise again, likely due to introduction of the World Wide Web graphical interface for the Internet and increased mass media coverage of the Information Superhighway (Zakon, online). By mid-decade millions of new users had come online to an increasingly commercial medium and with them they brought extremes of both enthusiasm and fear, especially on behalf of children (Grossman, 1997). In 1995, the US Congress debated the 'Protection of Children Act' that would eventually become the federal government's first attempt to regulate content on the Internet, the Communications Decency Act of 1996. In the 1997 decision Reno v. ACLU, the CDA was declared unconstitutional. This year was chosen as an ending point for a study of the early adoption of microcomputers because the Supreme Court redefined the Internet as a mass medium like television, marking a new phase in the cultural acceptance of the device. 


\section{A Multiperspectival Approach to Discourse}

Traditional diffusion theory is one approach that attempts to explain how innovations such as the computer are incorporated into daily life. It assumes that the attributes of an innovation as perceived by adopters, not as defined by inventors, is what affects its adoption (Rogers, 983). Winston (1998) and Fidler (1997) added that technology is rarely adopted on its merits alone; social forces both constrain and encourage adoption. Mass media is a significant influence, along with other social forces, in all stages of adoption (Rogers et al., 1982). Theorists who take a social constructionist view of technology adoption likewise assume that the ultimate use of a technology is determined by a complex social process that establishes new or reinforces existing power relationships among groups. According to Carolyn Marvin 'the focus of communication is shifted from the instrument to the drama in which existing groups perpetually negotiate power, authority, representation, and knowledge with whatever resources are available' (Marvin, 1988: 5)

While the adoption of microcomputers followed some of the patterns predicted and explained by diffusion theory, others have found it a 'peculiar innovation' that was introduced without a fixed or predefined function and was in a constant state of evolution. This peculiarity allowed symbolic importance to become a driving force in adoption (Caron et al., 1989; Winston, 1998). Therefore, an alternative to diffusion theory is needed in order to capture the complexities of the computer's adoption and to understand the role of the discourse surrounding the process.

Two theoretical approaches that investigate the connections between discourse, social practice and power relationships are Critical Discourse Analysis (CDA) and framing theory. CDA is a theory and methodology that assumes discourse is a form of 
social practice, a 'relationship between a particular discursive event and the situation(s), institutions and social structures which frame it' (Fairclough and Wodak, 1997: 258). Framing theory is primarily a media theory that considers social embeddedness of discourse as well. According to Stephen Reese, 'Frames are organizing principles that are socially shared and persistent over time, that work symbolically to meaningfully structure the social world' (Reese, 2001: 11). These 'frames' have been found to 'organize' in many ways, both cognitively and culturally.

Because the two theories share many assumptions and objectives, their synthesis offers new insights into texts. Hertog and McLeod (2001) argue that the role of social institutions in the development, maintenance, and challenge to frames has not been adequately studied. They therefore advocate a multiperspectival approach like that of the current study, which uses framing and CDA to draw direct linkages between texts and social practice (see also these studies of media coverage of computer technology: Hogan 2006, which combines traditional content analysis and CDA and Thurlow 2006's combination of linguistics and CDA.)

Both framing and CDA theories assume that texts, particularly media texts, are a site where various social groups, institutions, and ideologies struggle over the construction of social reality (Gamson and Modigliani, 1989; Hertog and Mcleod, 2001). They are also simultaneously reflective and influential of social structures and power relationships (Gitlin 1980). Both theories assume that influencing discourse is an 'exercise in power' (Reese, 2001: 10). In its 'explanation' phase, CDA sees 'discourse as part of processes of social struggle, within a matrix of relations of power' (Fairclough, 1989: 163). An essential connection between discourse and hegemony — as defined by Antonio Gramsci-is assumed in CDA; control over discursive practice is a struggle for 
dominance over orders of discourse. Because of their relationship to social practice and power, orders of discourse are a potential cultural hegemony themselves (Titscher et al., 2000). In CDA and framing both, language use is assumed to have an ideological component because it calls upon background understanding of existing social and cultural patterns as 'common sense.' Fairclough (1989) established that 'implicit assumptions' are a necessary part of all discourse, and are typically ideological in nature. Interpreters of text use these assumptions to fill in gaps in logic, usually with known information that sustains and reproduces existing power relationships.

Several studies of the adoption of personal computers, the Internet, and text messaging, (ICTs-Information and communications technologies), have considered the importance of media discourse in negotiations about adoption of the new technology (Haddon, 2007). For example, a detailed analysis of the way military worldview influenced discursive definitions of the technology, found a 'closed world discourse,' a language and set of practices that assumed computers made centralized command and control not only possible but also desirable (Edwards, 1996: 15). Other textual analyses of print media editorial and advertisements about computers have revealed sexism and boosterism (Warnick, 2002; Menosky, 1985; Weinstein, 1998). Cassidy’s qualitative analysis of magazine texts aimed at encouraging computer use by women found they promoted the post-feminist 'fantasy' of 'women's work' as centered at home raising children while at the same time earning outside income (2001). Reed (2000) found media texts sampled from the 1960 s to 1990 s to be 'normalizing discourses' that attempted to domesticate personal computers by relying 'heavily on very particular ideas and fears about appropriate gender and family relations' (p. 170; see also Wheelock, 1992). Thurlow (2006) found that print media articles about text messaging that used unnamed 
sources and unattributed examples reveal 'something of the institutional process by which news is fabricated' (p. 684)

The current study is also informed by studies of media discourse about ICTs that used combined methodologies, some of which hint at the situational and intertextual contexts of media discourse about computers and how discourses challenged or reinforced existing power relationships. Cogan's framing study (2005) of newspaper articles during the early 1980s found a preponderance of frames that depicted the computer as useful and friendly, those that employed metaphors of already accepted technology, such as automobiles, in order to encourage the public's adoption. He speculates, but does not explore, a connection between frames and the agendas of frame sponsors, observing that the 'frame of usefulness was no doubt very important to the computer industry and adequately reflected the aims and marketing strategies of the industry' (p. 264) Rossler's investigation of German news magazine discourse about the Internet found a preponderance of frames that provided 'favorable assessments' using argumentation patterns that, among other characteristics, 'evaluated the Internet as supporting the emancipation of the individual' (Rossler, 2001: 49). Yet when combined with an analysis of ICT user attitude data, additional complexities begin to be revealed; he suggests that media discourse was influential on some dimensions, such as pragmatic applications and the impression that the technology was a 'social must,' but 'the dominating patterns in our quantitative analysis of media coverage may have been not very convincing for internet users' (Ibid, p. 64).The current study suggests that these frames were not convincing because of 'discursive conflicts' within the texts that arise from the agenda of content producers to maintain the status quo. As James Carey has observed, 'while the technology overcomes many boundaries (of space and time, politics 
and economics), other social borders may be created at the same time. It is easier to see old boundaries coming down than to see new ones being erected' (Carey, 2005: 443).

The results of two quantitative analyses by this author began to expose the role of promotional agendas and priorities—both in advertisements and editorial stories—in a “frame building" process (Pan and Kosicki, 1993). Definitions of computer use that did not challenge existing social meanings were most prevalent, perhaps because they were most effective for 'normalizing' the technology (Author, 2004, 2003). The cases in the current study were derived from the same sample, in an attempt to investigate more closely evidence of the power relationships among media, sponsors, and audiences during this period of computer adoption. That is, the current study asks, How were particular social and cultural values ascribed to and reinforced by portrayals of microcomputers in order to promote acceptance of the devices?

\section{Method}

Quantitative studies by the author of 83 feature stories and 233 ads from 14 magazine titles published between 1974-1997 identified a manifest list of frames from the texts themselves and theoretical literature (see Table 1). ${ }^{1}$ Employing a definition of 'dominant frame' as that which was conveyed by the headline, lead subhead and first three paragraphs of both advertisements and editorial stories, these studies found that definitions that did not challenge existing social meanings were most prevalent. In the sample of advertisements, it was found that the most frequently appearing frame was that of tool, found to dominate 166 ads $(71.2 \%)$. In every year represented in the sample, the 
tool frame was the most frequently found in the advertisements. The literacy frame, which was used exclusively in ads depicting a use setting of home or school was the second most common frame (20 ads, $8.5 \%)$. The least common of all frames was selfreferential, which was employed in only one ad (.4\%).

In the sample of feature stories, the most frequently appearing frame was also tool, found to dominate 25 stories $(30.1 \%)$. This was followed by two frames that were potentially 'challenging' - personal (13 stories, $15.7 \%)$ and future $(11,13.3 \%)$, and one that supported the authority of parents and traditional definitions of individual achievement - literacy $(10,12 \%)$. The least common frames were all potentially challenging in their implications: self-referential, entertainment, and other, each of which dominated three stories (3.6 percent). A longitudinal analysis of these dominant frames over time revealed the virtual disappearance of the personal frame, which promised computers would invest power in individuals rather than traditional authorities. By 1984 only 3.2 percent of the stories included this frame.

These earlier studies suggested that the tool and literacy frames were favored by text producers because they were 'reinforcing,' supporting the authority of those in power (managers, parents), affirming middle-class aspirations for career success by assuming enhanced competitiveness in school and the workplace was a desirable goal, and ultimately creating consumer demand for a new, high-end durable good. Reinforcing aspects of other frames, such as danger, boundless, and future were also frequent. Frames such as self-referential, personal, and entertainment were less common because they portrayed the new devices as potentially decentralizing power by investing it in individuals, and otherwise 'revolutionizing' existing social structures. That is, these results were consistent with what Shoemaker and Reese see as the media's role in a 
hegemonic process, reinforcing 'American' ideology based on a belief in the values of capitalism, the Protestant work ethic, and individual achievement (Shoemaker and Reese, 1996: 222). 


\section{Table 1: Frame Definitions and Indicators}

\begin{tabular}{|c|c|c|}
\hline Frame name & Definition & Indicators \\
\hline Self-referential & $\begin{array}{l}\text { Primary reason/goal to own and use a } \\
\text { computer device is to learn how electronic } \\
\text { devices 'work,' how to repair them, or } \\
\text { how to program them. Little emphasis on } \\
\text { tasks. NOT 'easy' to understand/use. }\end{array}$ & $\begin{array}{l}\text { tinker, explore, troubleshoot on own, learn more about } \\
\text { information technology (IT), do it yourself. }\end{array}$ \\
\hline Appliance/Tool & $\begin{array}{l}\text { Tools used/that used to make business } \\
\text { functions and/or household chores, more } \\
\text { efficient and cost-effective, controlled, } \\
\text { productive, fast, and easy. Includes both } \\
\text { present and future capabilities of computer } \\
\text { devices. }\end{array}$ & $\begin{array}{l}\text { easy to understand; plug-it in 'out of the box'; anyone } \\
\text { can use it; has many uses, does the 'job' better; technical } \\
\text { specifications are highlighted; 'smart house' automation; } \\
\text { emphasizes speed, power, versatility, upgradeability; } \\
\text { justifies cost of technology because of } \\
\text { multifunctionality. }\end{array}$ \\
\hline Personal/Anthropomorphic & $\begin{array}{l}\text { Human-like, both extensions and } \\
\text { enhancements of one's personality, } \\
\text { creativity, and idea generation. Using } \\
\text { them will make one a better individual. }\end{array}$ & $\begin{array}{l}\text { 'personal computer'; what is on device same as person } \\
\text { who owns it; devices are same as humans: can think, be } \\
\text { friendly, talk; devices are smart and/or smarter than } \\
\text { humans; devices take out human intervention/judgment } \\
\text { from decisions; you can be all/anything with a computer; } \\
\text { interactive; 'computer brain.' }\end{array}$ \\
\hline Boundless/Networked & $\begin{array}{l}\text { Networks potentially 'limitless' in ability } \\
\text { to access and unify humans and } \\
\text { information. Subframe: Computers bring } \\
\text { people together from both close and far } \\
\text { physical distance. }\end{array}$ & $\begin{array}{l}\text { emphasis on email application; online community; } \\
\text { 'getting connected'; access to more information; } \\
\text { information = knowledge; too much data = information } \\
\text { overload; 'cyberspace' (Internet) = frontier; information } \\
\text { superhighway; promotes family harmony and } \\
\text { togetherness. }\end{array}$ \\
\hline Literacy & $\begin{array}{l}\text { Computer mastery is fundamental skill, so } \\
\text { children should use them. Skills needed } \\
\text { for academic and career success and will } \\
\text { become smarter. Subframe: Computers are } \\
\text { also inherently 'educational'; they make } \\
\text { learning easier. Subframe: Computers can } \\
\text { teach and supervise children without } \\
\text { parental/teacher involvement. }\end{array}$ & $\begin{array}{l}\text { educational use by children; computers make learning } \\
\text { fun; children and adults will learn quicker, without } \\
\text { boredom; better than human teachers; children better } \\
\text { with computers than adults; parents need to be literate in } \\
\text { order to stay close to children }\end{array}$ \\
\hline Futurism & Computers will dominate future life. & $\begin{array}{l}\text { don't be left out/behind; information revolution= } \\
\text { excitement, new opportunities; computers will eradicate } \\
\text { future social problems; references to new millennium; }\end{array}$ \\
\hline Entertainment & Computers are a pleasant diversion, fun. & $\begin{array}{l}\text { join friends in games, trade tips; reason to buy computer } \\
\text { is to play games; even multi-purpose computers work } \\
\text { best as games machines; games make computers } \\
\text { approachable, 'user-friendly' }\end{array}$ \\
\hline Danger* & $\begin{array}{l}\text { Computers can put adults, children, and } \\
\text { society in danger in some way. Use should } \\
\text { be mediated. }\end{array}$ & $\begin{array}{l}\text { dangerous to children; computers are threat to privacy, } \\
\text { health, psycho-logical, social well-being of children and } \\
\text { adults; hackers, hacking, and other crimes/criminals } \\
\text { (theft, abduction/abuse, stalking); viruses. }\end{array}$ \\
\hline
\end{tabular}

*Danger frame considered only in analyses of editorial texts.

A subset of the two samples used in these earlier studies were selected in order to investigate more closely the specific textual devices employed in these discourses and 
their linkage to institutional and social practice (Fairclough 1993). The specific cases were selected to represent a range of heterogeneity, across frames, text types, and time period. $^{2}$ The four case studies - two advertising and two editorial texts-were then subjected to all three stages of Fairclough's methodology, with only the 'explanation phase' reported here. In this stage the goal is to reveal how particular discourses were both ideologically determined and determinative, reinforcing, or challenging to existing social structures and power relationships. The four cases were:

- Case 1 was a 1983 full-page advertisement from Time magazine for a Texas Instrument Home Computer, with a dominant frame of tool and secondary frames of entertainment, literacy, boundless, and personal; the use setting was 'home' ('TI's Home Computer,' 1983). It depicted a family of five- - father, mother, son, two daughters—and the family dog gathered around a microcomputer sitting on a desk in a home-based office (Figure 1). The six paragraphs of text demonstrated characteristics of advertising or promotional discourse, first positioning the product favorably against its competition and then describing its features and utilities. The headline established 'expandability' as the device's primary selling point. 
Figure 1

Advertisement in Time Magazine, 1983

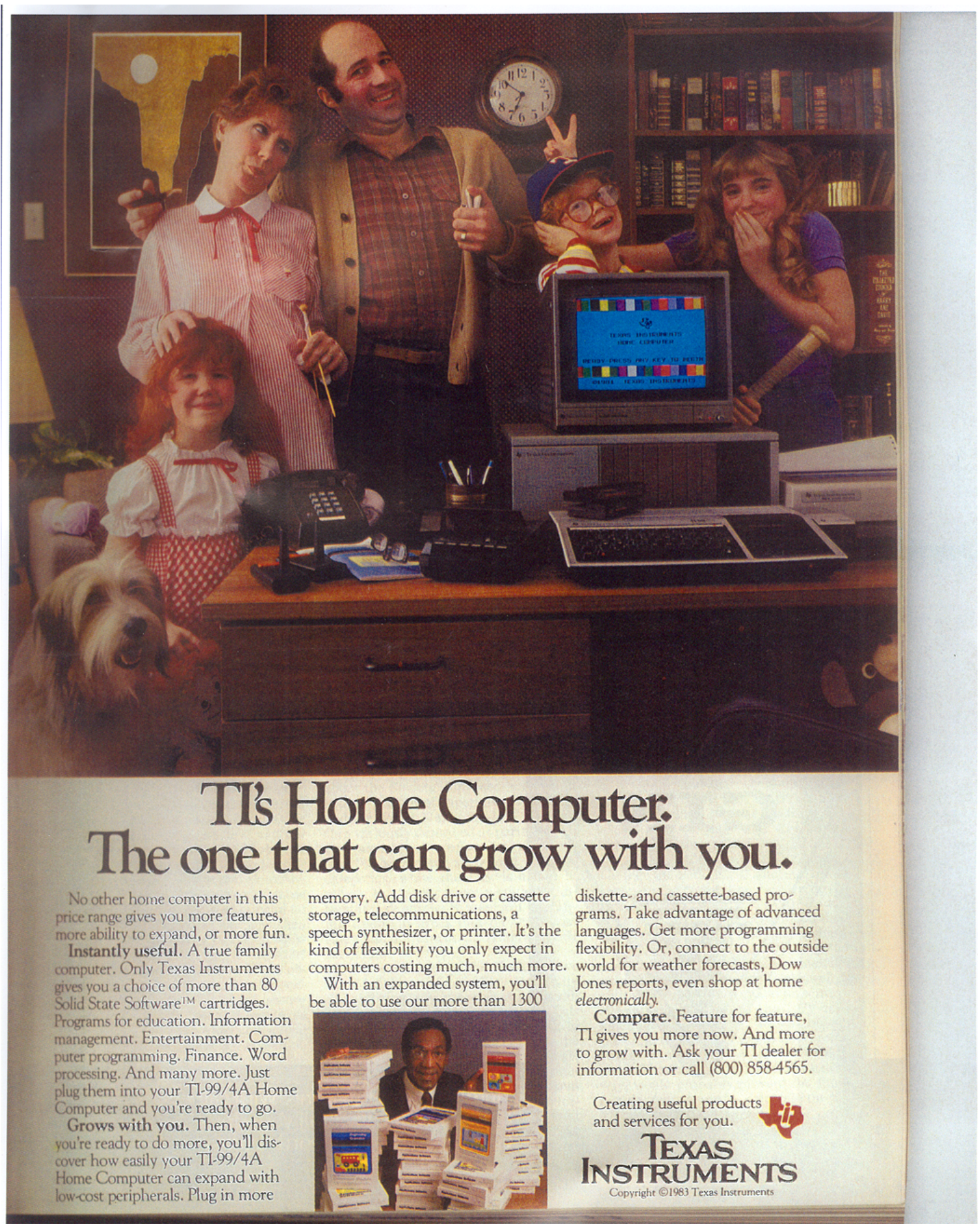


- Case 2 is a two-page, 1997 advertisement in National Geographic for Microsoft's Expedia travel services Web site, with a dominant frame of tool and secondary frames of boundless and personal. ('Book a Trip,” 1997). The full-color spread (Figure 2) promoted the features of Microsoft's Expedia travel services Web site by claiming 'Book a trip to solitude: Find hundreds of new activities to avoid.' After the headline and subhead, which established a theme of escaping from responsibility, four paragraphs of text established the specifications of the product and its benefits. The visual depicted a tropical-style grass hut at the end of a deserted boardwalk, a scene partially framed by the site's Web page frame (showing the URL, scroll bars, etc.). The boardwalk and ocean horizon, however, expanded beyond the border of the 'Web page' on all sides, suggesting that the audience had already arrived at the destination and was enjoying its 'solitude.'

Figure 2

Advertisement in National Geographic, 1997

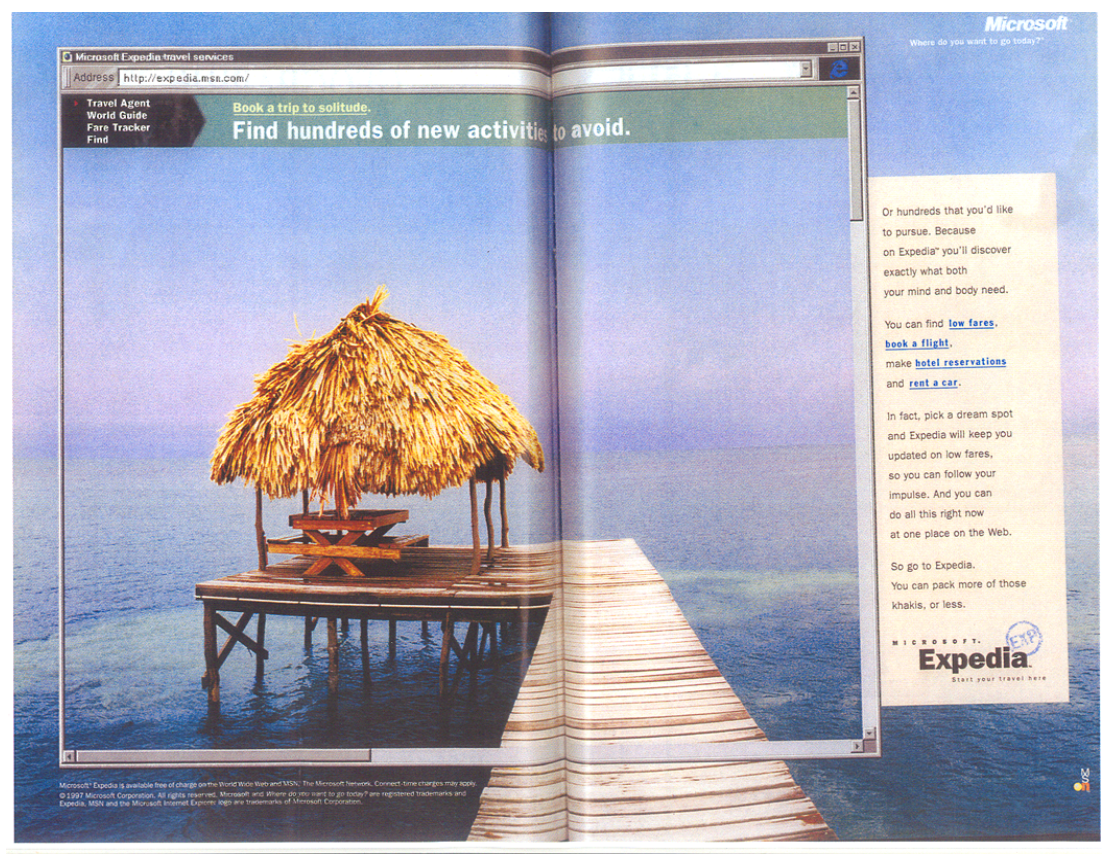


- Case 3 is a 1983 Time article, 73 paragraphs in length with a male byline, in which the microcomputer was named 'Machine of the Year' (Friedrich, 1983). Its dominant frame was tool; secondary frames represented were futurism, entertainment, literacy, boundless, personal, and danger. The presentation included eight color photographs. Paragraph 3 stated the theme that computers represented a revolution, used by the text producers to justify the choice of the computer as Machine of the Year, the first time a non-human was selected for the annual honor. Several potential 'problems' with computers were discussed, but the majority of the subthemes argued that the consequences of computerization would be positive. 
- a 1984 Parents article, 34 paragraphs in length with a female byline, with a dominant frame of literacy and secondary frames of futurism, boundless, and danger (Popper, 1984). It was a service article that dispensed advice and gave 'how-to' instruction regarding parental supervision of computer use by children. The story included two color photographs: a two-page spread showing a father, son, and daughter using a computer and a smaller image showing classroom use. It began by characterizing the concern of parents regarding use of computers by children as a 'problem,' and then attempted to establish ways computers were a positive influence on children and families. It summarized evidence that there was no cause for concern regarding computer use by children, and portrayed a mother whose fear about computers had been overcome.

Special emphasis was given in the analysis to text selections categorized as displaying one of the nine frames under consideration because, according to Fairclough, frames 'bear the ideological imprint of socially dominant power-holders that are likely to be a naturalized resource for all. In this way, thoroughly routine ways of appropriating and internalizing texts can be indirectly constrained by unequal relations of power' (Fairclough, 1989: 160-61). Assumptions within the frames, usually implied as 'common sense' or 'background knowledge' that had an ideological character, were identified and elaborated in an attempt to understand the power structures and value systems informing them. According to Fairclough 'the relations of power and domination and the ideologies which are build into these assumptions...make ordinary discourse practice a site of social practice of social struggle' (p. 162).

\section{Evaluation of Institutional and Societal Process}


These texts represented discourses arising from a complicated matrix of varied institutions and social processes: commercial interests manufacturing both products and providing services, advertising and public relations agencies, scientists and research institutions, print media publishers, government and military, public schools, even medicine and psychology. The discourses of these institutions represented both compatible interests - encouraging adoption by consumers of a particular technology as well as other products, such as magazines — and areas of potential struggle between ideologies and agendas. As discourse practice, the possibility for creative reconfiguration of genre and discourse types in order to communicate these interests seems limitless, but reconfiguration was constrained by the sociocultural practices of these institutions, and in particular by their relations of power.

For example, the texts studied existed within a system of capitalism, and the particular economies within this system shaped institutional practices and, in turn, texts of media. The press in the US functions within a highly competitive commercial environment, attempting to achieve the highest possible readerships in order to show a profit within a consumer market. All commercial media sell to advertisers the attention of their audiences, as a commodity. In this way media are a part of the consumer market, with close alignments and connections with industry. Therefore, publishers' interests are heavily invested in the overall success of the national and international economy. This dictates particular ideologies that shape features of texts, such as the favorable presentation of consumer products, as well as a more general 'pro-capitalist ethos.' The influence of this institutional reality can be seen in these case studies as the colonization of media discourse by the discourse of consumption (Fairclough, 1995). 
Discourse of Consumption

According to Fairclough and others, the dominance of capitalist values on an institutional level has lead to the 'colonization' of other discourses by the 'discourse of consumption' most notably the discourse of advertising (Garvey, 1995). ${ }^{3}$ This discourse was found in both the editorial and advertising cases in the form of promotional vocabulary and direct address to the audience as 'you.' For example, the text producers of Case 3 used evocative adjectives, overwording, and metaphors portraying the popularity and capabilities of computer technology in promotionally positive terms. Americans were said to have 'a giddy passion for the personal computer.' The technology was portrayed as 'so cheap, so powerful.' It was speculated that 'more and more offices' would soon do their work on computers (emphasis added by author). In Case 4, one passage suggested that the best regimen for solving the problems of computer use by children, as prescribed to the audience by the text producer, was consumer action. Parents were instructed to 'affect the market for quality software by becoming aware of what a good program entails.'

Especially before technological products such as computers become stabilized with certain agreed-upon characteristics, users play some role in finding different uses. Throughout the mid-1980s, for example, consumers decided computers were game machines, a manifestation captured by the entertainment frame. Yet when the audience of media texts accepted the role of consumer, they bought into a power relationship with text producers that allowed computer manufacturers to dictate which characteristics, features, and utilities computers possessed and what was considered as 'normal use' of them (Fairclough, 1993). 


\section{Maintaining Status Quo}

As economically embedded, media are also invested in maintaining the status quo (Fairclough, 1989). This investment has been suggested as the reason for the overwhelming reliance of journalists on official and otherwise legitimized sources, including government officials, business leaders, and scientific and technical experts from universities. The dominance of these sources has been documented in many media studies and was found in both of the editorial features here (Shoemaker and Reese, 1996; Soloski, 1989; Stempel and Culbertson, 1984).

Which frames were used in these cases and how they were used in combination revealed how these texts both they reflected and reinforced existing power relationships. In all four cases, the most common dominant frame was tool. For example, 20 of the 73 paragraphs and five of the seven visuals in Case 3 exploited the tool frame almost exclusively. The notion of utility as important would likely be accepted by the audience because it was based on accepted notions of utilitarianism embedded in the discourse of consumption. That is, the tool frame seemed a 'logical' one for audiences to call upon because it had been useful in making past consumer decisions. The ideological assumptions of the frame were also consistent with the values of capitalism and maintained the status quo of power relationships inherent in capitalism. It took at 'face value' the utilitarian capabilities of computers as defined by manufacturers, reinforcing military values inherent in the device from its origins: the importance of "command and control.' Early in Case 3 the authority of government and the military lent support to a list of uses of mainframes, including use as an efficient killing machine, stated euphemistically as 'electronically sophisticated forces' that have 'changed the way wars are fought.' This case also used analogy to show how, as a tool, computers were like 
other tools already accepted and in use. Though the technologies given as examples in the analogies were often only similar to computers in that they were mechanical devices (such as the automobile), these arguments did demonstrate 'familiarity,' a characteristic found in diffusion research to aid adoption (Rogers, 1983). This type of argumentation was particularly critical in the construction of the last paragraph, the 'transformation' ending that attempted to show the computer was not a threat because it was just another other 'gadget.' 'Perhaps the revolution will fulfill itself only when people... see their computer not as a fearsome challenger to their intelligence but as a useful linkup of some everyday gadgets: the calculator, the TV and the typewriter.'

The literacy frame was consistent with the values of the institution of capitalism because one of the primary reasons children were to become computer literate, whether stated explicitly or implicitly in texts, was so they could hold a particular kind of corporate job, likely in front of a computer. Traditionally, 'technologized' workers have been considered easy to manage and therefore not a threat to existing power structures (Yates, 1989). Also, the portrayal of children as future workers was consistent with the dominant American ideology identified by Shoemaker and Reese as valuing the work ethic and individual achievement. (Shoemaker and Reese, 1996).

When computers, especially the Internet, first entered homes and schools, children had potentially unprecedented wide and easy access to information once reserved for adults, some of it harmful. Not only did children find information, they stayed engaged with the new medium for long periods of solitary use, often playing games. Therefore, the computer produced fears in parents of social isolation from their children and loss of control over children's knowledge and behavior. The literacy frame, therefore, served as a creative discursive solution that could alleviate these fears because 
it operated within the constraints of acceptable familial relations: parents remained the authorities who made decision about computer purchase, location, and use, favoring, of course, 'appropriate' — that is 'educational'—-software. By analogy, knowledge of the computer was made equivalent with the already accepted notion of traditional literacyreading. Using computers for educational (rather than entertainment) purposes was a way to reinforce adult control over children, based on rules and other models of good behavior. For example, Case 4 reported anecdotal evidence from teachers that 'former truants now fight for time to use the computers.' The article included photographs of well-behaved students working intently on school work.

In Cases 3 and 4, the literacy frame was also used to assuage a wide range of parental guilt and fear. Parents no longer needed to feel neglectful for allowing children to use computers for long periods of time unsupervised because the activity was inherently educational. They needn't worry that their children were more technologically savvy than adults because that knowledge guaranteed good jobs in the future. The literacy frame also presented computers as a technological panacea rather than an economic or administrative solution for failing schools, thereby reinforcing and reproducing existing structures in education as well.

Although it was implicitly argued in Case 3 that adults needed to become computer literate, it was more explicitly stated in Case 4. Along the way biases about computer use by women were revealed. When computers were introduced it was predicted that they would both decentralize and degender the workplace (Reed, 2000). During the computer buying slump in the 1980s in particular, manufacturers realized that female consumers represented an untapped market (Cassidy 2001). But because the use of computers by women was a potential threat to traditional gender roles, discourses 
about women using technology were creativity constrained. In Case 1, for example, it was males of the household who adopted the technology and women who were, often unwillingly, forced to accommodate the device in their homes. Case 3's photo shows a pregnant mother who is rolling her eyes as her daughters act uninterested in the device that cause both the father and son to beam with pride. In Case 4 , one mother was 'scolded' by her son for her lack of computer knowledge, and another is 'converted' by her son. In this text, both the lead and transformative ending assumed parents-mothers in particular-had 'a problem' with computers and therefore, were those who needed to become computer literate in order to stay close to their children. 'I think my son cured my apprehensiveness when he assured me that the computer only follows my instructions,' said a mother in the final paragraph.

\section{Pragmatism Predominates}

In all four cases the arguments used within the tool frame were strong enough make it a kind of 'super frame,' one that dictated that the most utilitarian characteristics embedded in other frames would be emphasized. In Case 2 both the main visual and text (Paragraph 4 'pick a dream spot') employed the boundless frame, which suggests that a computer allowed the user to escape physical boundaries, visiting exotic locales either in reality or virtually. However, the tool frame dominated the text, if not by quantity of references, by placement. The headline 'Book a trip to solitude,' emphasized the utilitarian nature of the Web service for making travel arrangements. That is, the tool frame co-existed with frames that potentially threatened existing power structures: boundless and personal (impulsiveness). It even seems to suggest that the computer allowed escape while at work. In this case the combination yielded textual 
inconsistencies (mixed messages) that are evidence of what Fairclough's calls a 'discursive struggle' between text producers and opponents, which leads to novel restructuring of discourse types (Fairclough, 1989).

Even Case 3, which ostensibly touted the revolutionary potential of Time's Machine of the Year, the article emphasized utilitarianism. Instead of meaning the ability to bridge social distance, "boundlessness" was interpreted as a way workers could telecommute, thereby increasing business profits and lowering overhead costs. This discussion used the boundless frame to reinforce existing power relationships, not revolutionize them in other ways as well, noting that computers were 'particularly rich with promise' for two marginalized groups of workers: 'women who feel tied at home because of young children' and the physically handicapped. At its core the argument in favor of telecommuting was ideologically loaded because it assumed that the best (and only) solution for accommodating these workers was their staying at home, ignoring the possibility that the traditional office environment could be altered to assimilate them. One extended anecdote about a telecommuting mother demonstrated a discursive struggle, in fact showing how ineffective the woman was at performing two jobs simultaneously:

'The computer in her cream-colored stucco house in South Minneapolis is surrounded by children's books, laundry, a jar of Dippity Do. ... “At 11:30 comes Sesame Street and Mr. Rogers, so that's when I usually get a whole lot done."”

That is, in two of these cases, the boundless frame was used to encourage women to earn income outside of the household, but only while remaining isolated in the home and maintaining traditional roles as housekeepers and mothers (Cases 1 and 3). Even into 
the 1990s, these gendered aspects of computer technology continued to influence how users were 'configured' (Reed, 2000). Warnick (2002) observed that much of the rhetoric in the popular press disempowered women by blaming them for not being more technologically savvy and ignoring the economic and lifestyle realities that made it difficult to embrace computers

Even the potentially disruptive aspects of the danger frame could be super-framed by utilitarian aspects of the tool frame. Case 3 made two mentions of the same potential danger arising from children's work with computers, that kids might become hackers. But as evidence of the dominance of the utilitarian definitions, this risk was downplayed as being innocent and then reframed as a benefit—a job skill:

'They [children] delight in cracking corporate security and filching financial secrets, inventing new games and playing them on military networks, inserting obscene jokes into other people's programs. In soberer versions that sort of skill will become a necessity in thousands of jobs opening up in the future.'

\section{Recasting Challenging Frames}

The potentially challenging personal frame was not only discredited in these texts, it was also recast in a way that reinforced existing social processes. In Case 3 the fear that computers could potentially outthink humans was disputed using a metaphor found to be common for the danger of artificial intelligence: HAL, the murderous device in the feature film 2001: A Space Odyssey. The text concluded, without specific counterexamples or support from authoritative sources (other than the reporters), that 'There has been much time wasted on the debate over whether computers can be made to think. That answer is simple: computers do not think.' Elsewhere in the text, the most challenging 
aspects of this frame were reframed as a benefit: smart computers could improve how children think, improving how they performed within the traditional educational system.

According to Woolgar (1991) and Reed (2000), manufacturers and distributors have the power to configure the relationship between computer users and devices by prescribing acceptable forms of access and use. For years companies struggled to convince their audience that computers were not game machines, but rather capable of 'serious' applications (Haddon and Skinner, 1991; Murdoch et al., 1992). While the text of Case 1 claimed a particular computer was 'more fun' than others, the entertainment frame was outweighed or super framed by the much larger quantity of counter examples of applications such as programming. In Case 3 the presentation of the entertainment frame revealed possible discursive struggles that could be evidence of novel restructuring of discourse types. That is, the frame was made by the text producers to be invalid and inconsistent with the goals of the text, the subject positions of the participants, etc. For example, when examples of the popularity of games were presented, it was with loaded language and negative analogies. 'This most visible aspect of the computer revolution, the video game, is its least significant' (emphasis added by author). Games were characterized as 'teen-age fad,' comparable to the by-then unpopular Rubik's Cube and hula hoop. When games were credited with making all computers easier to understand and less intimidating, the vocabulary was qualified, such as 'games have educational value, by teaching logic, or vocabulary, or something' and 'probably the most important' (emphasis added).

Discussion: Reinforcing Frames as Marketable 
Taken together, these four texts show how 'reinforcing' frames were favored and how they were implemented by text producers, both advertisers and magazine writers. As suggested by Garvey in her study of the adoption of bicycles, text producers had a vested interest in encouraging adoption. They gravitated toward known definitions because they hoped to convince readers to accept a new product that could be advertised within their pages. They 'took on the project of defusing the threatening commodity and making it salable' (Garvey, 1995: 82). They therefore had to find a way to make a device that was potentially 'revolutionary' and threatening because of its promise of effecting cataclysmic change, seem somehow 'normal.' Frames such as tool, literacy, and boundless drew on accepted notions about and definitions of technology such as utility, control, and skill betterment.

Specifically the results demonstrates how reinforcing frames drew on particular ideologies, such as capitalism, individualism, and consumerism, and how these ideologies were shaped by power relations at institutional and societal levels, particularly the dominance of men over women, parents over children, managerial class over working class, government over citizens, and producers over consumers. Also, conclusions can be drawn about how particular frames were employed in order to reframe or discount risks of computers and associate the technology with already-accepted power relationships and values in order to encourage their acceptance and adoption. And finally, the analysis determines how particular values and characteristics inherent in existing power relations were associated with an object - the microcomputer-in order to promote its acceptance, and how this in turn sustained these existing power relations rather than challenging them. 
Both advertising and editorial texts, when presenting potentially challenging frames, actively discredited them, or used the frames only to support other frames. These frames did not work as well as reinforcing frames for normalizing the technology because they potentially challenged existing habits, values, social structures, and power relations. They were therefore missing in texts or present only in a backgrounded way; for example, the self-referential frame didn't appear in any of these cases.

The following conclusions may therefore be drawn: 1) popular magazine texts portrayed computers in a way that encouraged their adoption by using 'reinforcing' frames or aspects of frames; 2) editorial and advertising texts were similar in their use of frames, using the promotional language of the discourse of consumption 3) text producers had similar goals, which were constrained by similar influences at individual, media routine, organization, extramedia, and ideological levels.

A great deal more solid, systematic research is needed into how, why, and to what extent social institutions, including media, define and ascribe cultural meaning to technology in general and to microcomputers specifically. For example, more work needs to be done to identify the sources of frames and subframes ascribed to technology products and how these frames might be articulated differently in cultural products ranging from popular film to children's textbooks. This sample, as well as others, could be subjected to analysis that attempts to define discrete cycles in framing. Based on the definitions of framing cycles developed by Miller and Riechert (2001), this type of analysis would allow for more direct correlations with persuasive efforts by computer sponsors and their effects. Others have hinted at such patterns in science and technology reporting but have not quantified and tested these theories (Nelkin, 1987). Rossler's (2001) finding that a frame analogous to the personal frame ('emancipation 
consequence') reemerged in the late 1990s in media discourse about the Internet. Also, subjecting texts of computer technology sponsors, such as press releases by computer manufacturers and government documents, to the same frame analysis and tracking this influence on media texts would enhance knowledge about extramedia influences on media content (Miller and Reichert, 2001) Here the relationships between government, industry, regulation, and tax structure, and so on, as influence on public discourse could be explored. 


\section{Endnotes}

${ }^{1}$ Titles from which feature stories were sampled included Time, Newsweek, US News, Money, Nation's Business, Business Week, McCall's, Better Home and Gardens, House Beautiful, Parents, Working Mother, Reader's Digest. Titles from which full-page advertisements were sampled included Reader's Digest, National Geographic, Better Homes \& Gardens, Parents, Time, and Family Circle. (Author, 2001).

${ }^{2}$ Although the two editorial texts do not represent great variety in publication dates, they were selected based on evidence in the preliminary reading suggesting they demonstrate relevant frames characteristics that remained constant across the time period, a method suggested by Fairclough (1993: 145).

${ }^{3}$ Garvey uses but does not define 'discourse of consumption' Fairclough (1989: 206), uses and defines the term 'discourses of consumerism' as a group of discourses that includes advertising and bureaucratic discourse. 


\section{References}

"Book a Trip to Solitude" (1997) Advertisement for Microsoft Expedia Web site, National Geographic 191 (6): 9-10.

Campbell-Kelly, M. and W. Aspray (1996) Computer: A History of the Information Machine. New York: Basic.

Carey, J. W. ( 2005 ) "Historical Pragmatism and the Internet," New Media \& Society 7 (4): 443.

Carlton, J. (1997) Apple: The Inside Story of Intrigue, Egomania, and Business Blunders. New York: Times Business.

Caron, A., L. Giroux and S. Douzou (1989) "Uses and Impacts of Home Computers in Canada: A Process of Re-appropriation," in J. Salvaggio and J. Bryant (eds.) Media Use in the Information Age: Emerging Patterns of Adoption and Consumer Use. New Jersey: Hillsdale.

Cassidy, M. (2001). “Cyberspace Meets Domestic Space: Personal Computers, Women’s Work and the Gendered Territories of the Family Home," Critical Studies in Media Communication 18 (1) 44-63. 
Cogan, B. (2005) "Framing Usefulness: An Examination of Journalistic Coverage of the Personal Computer from 1982-1984," Southern Communication Journal 70 (3): 248-65.

Edwards, P. (1996). The Closed World: Computers and the Politics of Discourse in Cold War America Cambridge, Mass.: MIT Press.

Fairclough, N. (1989). Language and Power. New York: Longman.

Fairclough, N. (1993) "Critical Discourse Analysis and the Marketization of Public Discourse: the Universities," Discourse \& Society 4 (2): 133-68.

Fairclough, N. (1995). Media Discourse. New York: Edward Arnold.

Fairclough, N. and Ruth Wodak, (1997) "Critical Discourse Analysis: An Overview," in T.van Dijk (ed.) Discourse and Interaction, pp. 258-84. London: Sage.

Fidler, R. (1997). Mediamorphosis: Understanding New Media. Thousand Oaks: Pine Forge

Freiberger, P. and M. Swaine. (1984). Fire in the Valley: The Making of the Personal Computer. Berkeley, Calif: Osborne/McGraw-Hill. 
Friedrich, O. (1983) “The Computer Moves In: Machine of the Year,” Time 121 (1): 1424.

Gamson, W. and A. Modigliani. (1989). "Media Discourse and Public Opinion on Nuclear Power: A Constructionist Approach," American Journal of Sociology 95 (vol?): $1-37$.

Garvey, E. G. (1995) "Reframing the Bicycle: Advertising Supported Magazines and Scorching of Women," American Quarterly 47 (1): 66-101.

Gilster, P. (1997). Digital Literacy. New York: Wiley.

Gitlin, T. (1980) The Whole World Is Watching: Mass Media in the Making and Unmaking of the New Left Berkeley, Calif.: University of California Press.

Grossman, W. M. (1997). Net.Wars. New York: New York University.

Haddon, L. (2007). “Roger Silverstone’s Legacies: Domestication,” New Media \& Society 9 (1): 25-32.

Haddon, L. and Skinner, D. (1991) "The Enigma of the Micro: Lessons from the British Home Computer Boom.” Social Science Computer Review 9 (4): 435-49. 
Hertog, J. K. and McLeod, D. M. (2001) “A Multiperspectival Approach to Framing Analysis: A Field Guide," in S. Reese et. al. (eds.) Framing Public Life, pp. 139-61. Mahwah, N.J.: Lawrence Erlbaum.

Hogan, J. (2006) "Letters to the Editor in the 'War on Terror': A Cross-National Study," Mass Communication and Society 9 (1): 63-83.

Johnson, B. (1990) "Yule cheer lacking for PCs." Advertising Age (Nov. 12), S-1-2.

Author (2004) 'The Framing of Microcomputers in Magazine Features, 1973-1997,' paper presented to Magazine Division at the Association for Education in Journalism and Mass Communication's Annual Meeting, Toronto, August.

(2003) 'Selling Silicon: The Framing of Microcomputers in Magazine Advertisements, 1974-1997,' paper presented to the Magazine Division at the Association for Education in Journalism and Mass Communication's Annual Meeting, Kansas City, August.

Marvin, C. (1988) When Old Technologies Were New: Thinking about Electric Communication in the Late Nineteenth Century. New York: Oxford University. 
Miller, M. and Riechert, B. (2001) 'The Spiral of Opportunity and Frame Resonance: Mapping the Issue Cycle in News and Public Discourse,' in S. Reese et. al. (eds.) Framing Public Life, pp. 107-21. Mahwah, N.J.: Lawrence Erlbaum.

Marx, L. and Smith, M. (1994) 'Introduction.' In Does Technology Drive History: The Dilemma of Technological Determinism, pp. ix-Xv. Cambridge, Mass.: MIT Press.

Menosky, Joseph A. (1985) 'Computer Literacy and the Press.' In D. Sloan (ed.), The Computer in Education: A Critical Perspective, pp. 77-83. New York: Teachers College Press.

Murdock, G. et. al. (1992). 'Contextualizing Home Computing: Resources and Practices.' In R. Silverstone and E. Hirsch (eds.), Consuming Technologies: Media and Information in Domestic Spaces, pp. 146-60. New York: Routledge.

Pan, Z. and G. Kosicki (1993) 'Framing Analysis: An Approach to News Discourse,' Political Communication 10 (): 55-75.

Papadakis, M. and E. Collins (2001) 'The Application and Implications of Information Technologies in the Home: Where are the Data and What Do They Say? National Science Foundation, Division of Science Resources Studies. NSF 01-131.

Petre, P.E. (1983) 'Mass-marketing the Computer.' Fortune 108 (October 31): 61-67. 
Popper, A. (1984) ‘Kid-Friendly Computers’ Parents 59 (June): 76-79.

Reed, L. (2000) 'Domesticating the Personal Computer: The Mainstreaming of a New Technology and the Cultural Management of a Widespread Technophobia, 1964_.' Critical Studies in Media Communication 17 (2):159-85.

Reese, S. (2001) 'Prologue_Framing Public Life: A Bridging Model for Media Research' In S. Reese, et. al (eds.), Framing Public Life, pp. 7-31. Mahwah, N.J.: Erlbaum.

Robertson, D. (1998) The New Renaissance: Computers and the Next Level of Civilization. New York: Oxford University Press.

Rogers, E. (1983) Diffusions of Innovations. New York: Free Press.

Rogers, E, H. Daley, and T. Wu. (1982) 'The Diffusion of Home Computers: An Exploratory Study.' ERIC ED 235786.

Rossler, P. ( 2001) 'Between Online Heaven and Cyberhell,' New Media \& Society 3 (1): 49-66. 
Shoemaker, P. and S. Reese. (1996). Mediating the Message: Theories of Influences on Mass Media Content. White Plains, N.Y.: Longman.

Soloski, J. (1989) 'Sources and Channels of Local News.' Journalism Quarterly 66 (4): 864-70.

Spigel, L. (1992) Make Room for TV: Television and the Family Ideal in Postwar America. Chicago: University of Chicago.

Stempel, G. and H. Culbertson, (1984) 'The Prominence and Dominance of News Sources in Newspaper Medical Coverage.' Journalism Quarterly 61(3): 671-76.

Thurlow, C. (2006) 'From Statistical Panic to Moral Panic: The Metadiscursive Construction and Popular Exaggeration of New Media Language in the Print Media,' Journal of Computer-Mediated Communication 11: 227-701.

'TI’s Home Computer.' (1983) Texas Instruments advertisement, Time 121(April 18): 25.

Titscher, S., M. Meyer, R. Wodak, and E. Vetter (2000) Methods of Text and Discourse Analysis. Thousand Oaks, Calif.: Sage.

Titus, J.A. (1974) 'Build the Mark-8 Minicomputer.' Radio-Electronics 45 (July): 29-33. 
S. Turkle. (1995) Life on the Screen: Identity in the Age of the Internet. New York: Touchstone.

Warnick, B. (2002) Critical Literacy in a Digital Era. Mahwah, N.J.: Lawrence Erlbaum.

Weinstein, M. (1988) 'Computer Advertising and the Construction of Gender.' In H.

Bromley and M. Apple (eds.), Education/Technology/Power: Educational Computing as Social Practice, pp. 85-100. New York: SUNY.

Westrum, R. (1991) Technologies and Society: The Shaping of People and Things. Belmont, Calif.: Wadsworth.

Winston, B. (1998) Media Technology and Society: A History from the Telegraph to the Internet. New York: Routledge.

Woolgar, S. (1991) 'Configuring the User.' In J. Law (ed), The Sociology of Monsters: Essays on Technology, pp. New York: Routledge.

Yates, JoAnne. (1989) Control through Communication: The Rise of System in American Management. Baltimore: Johns Hopkins University Press.

Zakon, R. (continuously updated) 'Hobbes Internet Timeline.' URL (consulted July 2008) http://zakon.org/robert/internet/timeline. 
Table 1: Frame Definitions and Indicators

\begin{tabular}{|c|c|c|}
\hline Frame name & Definition & Indicators \\
\hline Self-referential & $\begin{array}{l}\text { Primary reason/goal to own and use a } \\
\text { computer device is to learn how electronic } \\
\text { devices 'work,' how to repair them, or } \\
\text { how to program them. Little emphasis on } \\
\text { tasks. NOT 'easy' to understand/use. }\end{array}$ & $\begin{array}{l}\text { tinker, explore, troubleshoot on own, learn more about } \\
\text { information technology (IT), do it yourself. }\end{array}$ \\
\hline Appliance/Tool & $\begin{array}{l}\text { Tools used/that used to make business } \\
\text { functions and/or household chores, more } \\
\text { efficient and cost-effective, controlled, } \\
\text { productive, fast, and easy. Includes both } \\
\text { present and future capabilities of computer } \\
\text { devices. }\end{array}$ & $\begin{array}{l}\text { easy to understand; plug-it in 'out of the box'; anyone } \\
\text { can use it; has many uses, does the 'job' better; technical } \\
\text { specifications are highlighted; 'smart house' automation; } \\
\text { emphasizes speed, power, versatility, upgradeability; } \\
\text { justifies cost of technology because of } \\
\text { multifunctionality. }\end{array}$ \\
\hline Personal/Anthropomorphic & $\begin{array}{l}\text { Human-like, both extensions and } \\
\text { enhancements of one's personality, } \\
\text { creativity, and idea generation. Using } \\
\text { them will make one a better individual. }\end{array}$ & $\begin{array}{l}\text { 'personal computer'; what is on device same as person } \\
\text { who owns it; devices are same as humans: can think, be } \\
\text { friendly, talk; devices are smart and/or smarter than } \\
\text { humans; devices take out human intervention/judgment } \\
\text { from decisions; you can be all/anything with a computer; } \\
\text { interactive; 'computer brain.' }\end{array}$ \\
\hline Boundless/Networked & $\begin{array}{l}\text { Networks potentially 'limitless' in ability } \\
\text { to access and unify humans and } \\
\text { information. Subframe: Computers bring } \\
\text { people together from both close and far } \\
\text { physical distance. }\end{array}$ & $\begin{array}{l}\text { emphasis on email application; online community; } \\
\text { 'getting connected'; access to more information; } \\
\text { information = knowledge; too much data = information } \\
\text { overload; 'cyberspace' (Internet) = frontier; information } \\
\text { superhighway; promotes family harmony and } \\
\text { togetherness. }\end{array}$ \\
\hline Literacy & $\begin{array}{l}\text { Computer mastery is fundamental skill, so } \\
\text { children should use them. Skills needed } \\
\text { for academic and career success and will } \\
\text { become smarter. Subframe: Computers are } \\
\text { also inherently 'educational'; they make } \\
\text { learning easier. Subframe: Computers can } \\
\text { teach and supervise children without } \\
\text { parental/teacher involvement. }\end{array}$ & $\begin{array}{l}\text { educational use by children; computers make learning } \\
\text { fun; children and adults will learn quicker, without } \\
\text { boredom; better than human teachers; children better } \\
\text { with computers than adults; parents need to be literate in } \\
\text { order to stay close to children }\end{array}$ \\
\hline Futurism & Computers will dominate future life. & $\begin{array}{l}\text { don't be left out/behind; information revolution= } \\
\text { excitement, new opportunities; computers will eradicate } \\
\text { future social problems; references to new millennium; }\end{array}$ \\
\hline Entertainment & Computers are a pleasant diversion, fun. & $\begin{array}{l}\text { join friends in games, trade tips; reason to buy computer } \\
\text { is to play games; even multi-purpose computers work } \\
\text { best as games machines; games make computers } \\
\text { approachable, 'user-friendly' }\end{array}$ \\
\hline Danger* & $\begin{array}{l}\text { Computers can put adults, children, and } \\
\text { society in danger in some way. Use should } \\
\text { be mediated. }\end{array}$ & $\begin{array}{l}\text { dangerous to children; computers are threat to privacy, } \\
\text { health, psycho-logical, social well-being of children and } \\
\text { adults; hackers, hacking, and other crimes/criminals } \\
\text { (theft, abduction/abuse, stalking); viruses. }\end{array}$ \\
\hline
\end{tabular}

*Danger frame considered only in analyses of editorial texts. 
Figure 1

Advertisement in Time Magazine, 1983 


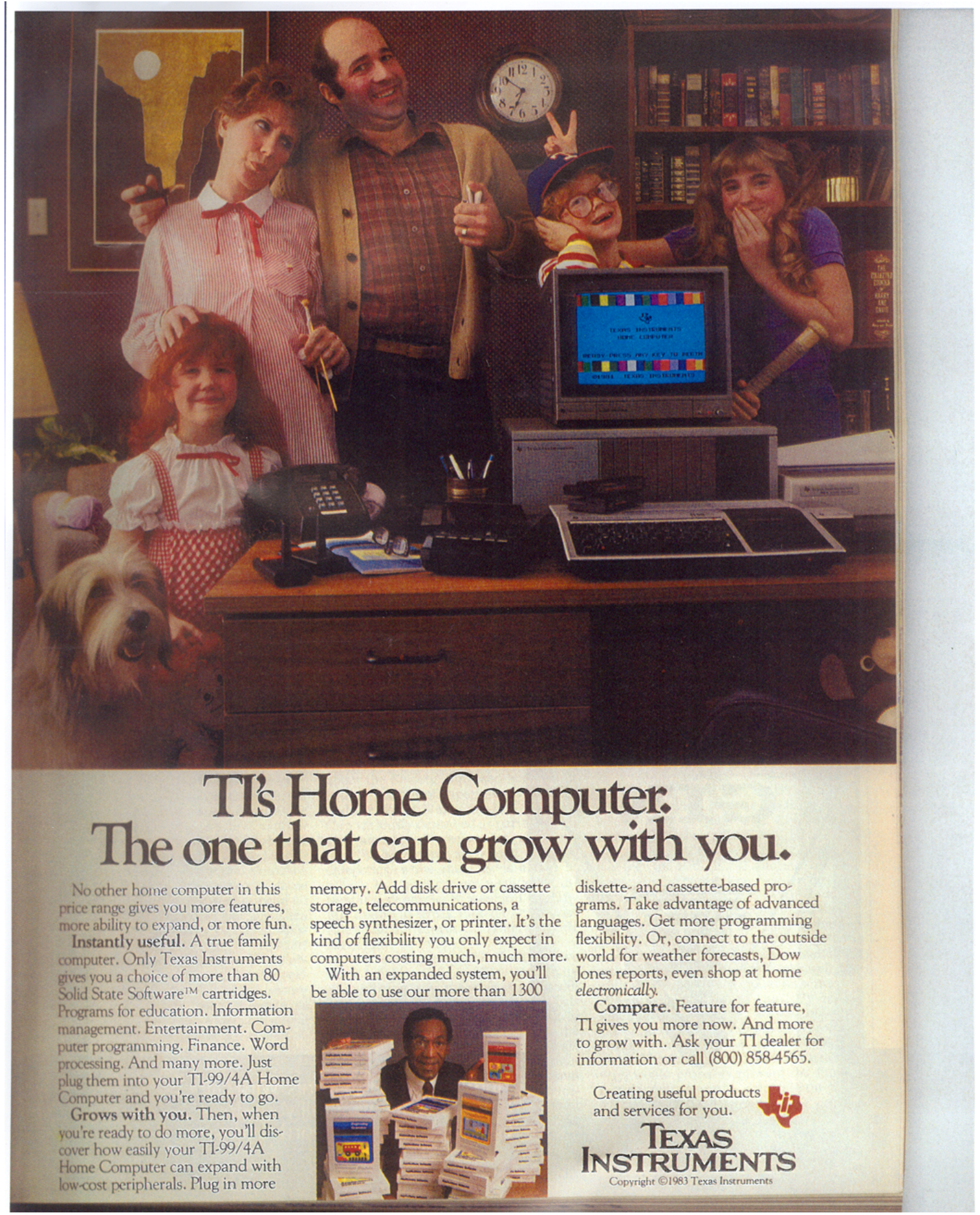


Figure 2

Advertisement in National Geographic, 1997

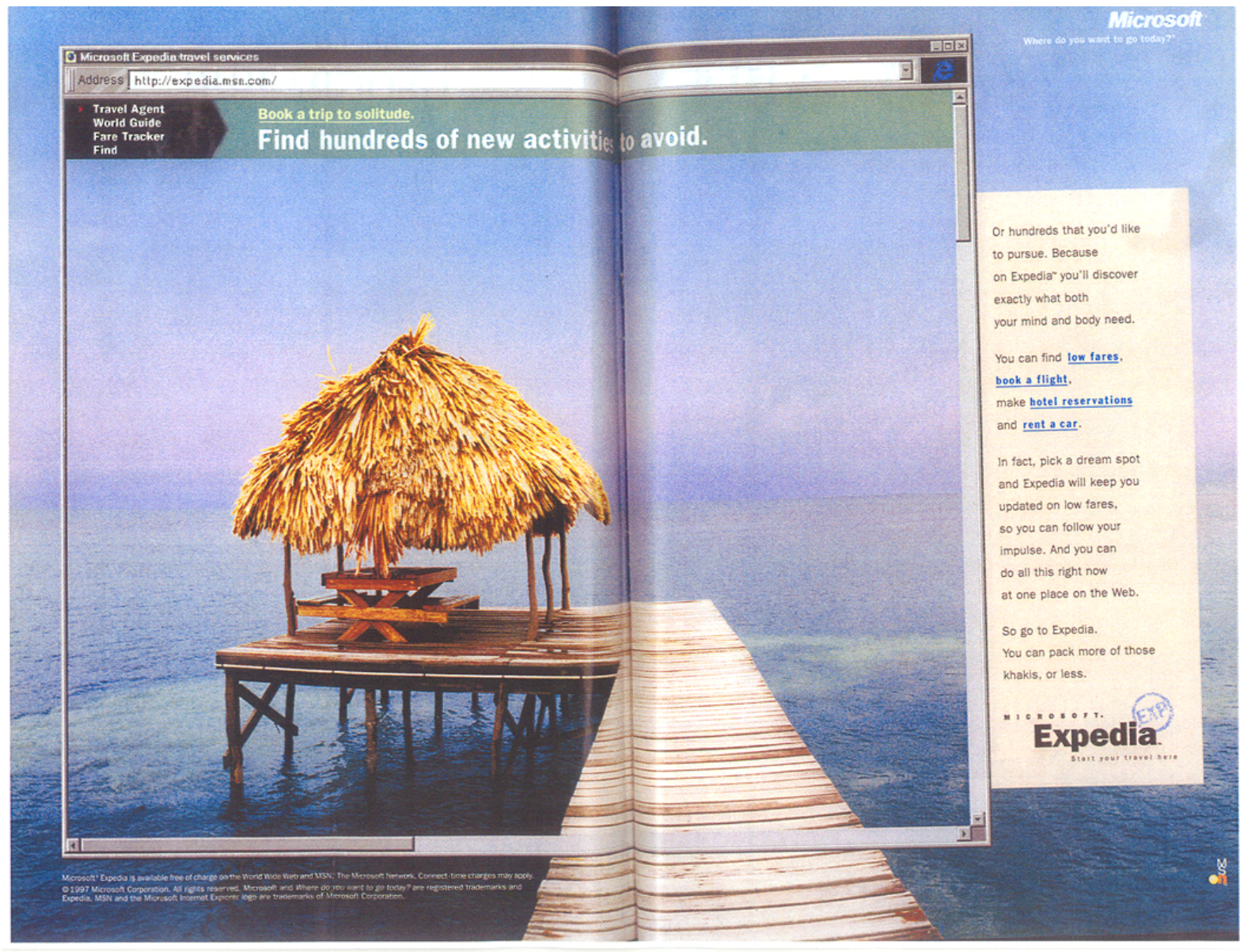

